EDUKACJA MIĘDZYKULTUROWA

2013, nr 2

ISSN 2299-4106

\title{
WIKTOR RABCZUK
}

\section{Czynniki niesprzyjające i chroniące w przebiegu kariery szkolnej uczniów imigrantów}

Streszczenie: Artykuł ukazuje zasięg zjawiska imigracji i jej znaczenie społeczno-ekonomiczne w krajach OECD oraz polepszenie w ostatniej dekadzie poziomu wykształcenia dzieci imigrantów. Jednak kształcenie dzieci imigrantów pozostaje nadal poważnym wyzwaniem dla systemów szkolnych. Są oni narażeni na stres kulturowy, toteż ich adaptacja szkolna jest utrudniona. Chociaż wywodzą się ze środowisk defaworyzowanych, osiągają jednak względnie lepsze wyniki akademickie, aniżeli populacja autochtoniczna o podobnym statusie społeczno-ekonomicznym. Aby wyjaśnić to zjawisko, pożądane jest uwzględnienie pojęć resilience i kapitału społecznego. Termin kapitał społeczny pozwala wyeksponować relacje korzystne („dobry” kapitał społeczny) dla rozwoju kapitału ludzkiego, pojęcie zaś resilience umożliwia ujmowanie tych relacji jako czynników chroniących uczniów w sytuacjach niesprzyjających i trudnych. Zrelacjonowane badania szwajcarskich autorek, D. Bader i R. Fibbi, mieszczą się w nurcie badań nad fenomenem resilience. Artykuł kończy się refleksją autora o doniosłej roli normatywnego wymiaru kapitału kulturowego imigrantów (pochodzenia azjatyckiego), który w sposób szczególny przyczynia się do procesów pozytywnej adaptacji szkolnej i społecznej ich dzieci, powiększając zasoby czynników chroniących.

Słowa kluczowe: uczniowie pochodzenia imigranckiego, adaptacja szkolna, kapitał społeczny, czynniki chroniące

Procesy migracyjne nie tylko nie ustają, lecz wręcz nasilają się współcześnie. Wszystko wskazuje na to, że migracje międzynarodowe będą ewoluować w podobny sposób, jak wymiany handlowe, tj. stale się powiększając. Prawie wszystkie kraje i regiony mają do czynienia ze zjawiskiem imigracji i emigracji. Ich nieuchronną konsekwencją jest różnicowanie się kulturowe, społeczne, ekonomiczne i religijne głównych krajów docelowych migracji. Unia Europejska, Organizacja Współpracy Gospodarczej i Rozwoju niezmiennie podkreślają, że od pokoleń migracja znacznie przyczyniała się do rozwoju społeczno-ekonomicznego krajów przyjmujących i będzie tak również 
w przyszłości. Obecnie, w czasach narastającej globalizacji i zmian demograficznych, pomyślna integracja imigrantów w społeczeństwie nadal warunkuje konkurencyjność gospodarczą oraz stabilność i spójność społeczną.

Imigranci w 2010 roku stanowili blisko dziesięć procent mieszkańców krajów należących do Organizacji Współpracy Gospodarczej i Rozwoju. W stosunku do roku 2000 jest to dwudziestopięcioprocentowy wzrost. Proporcja imigrantów w Hiszpanii wzrosła trzykrotnie między rokiem 2000 a rokiem 2010, zaś w Islandii i Irlandii ponad dwukrotnie. Tylko kilka krajów nie odnotowało znaczącego wzrostu, należą do nich Niemcy, Stany Zjednoczone, Francja i Holandia. Według OECD poziom wykształcenia imigrantów polepszył się, co przekłada się na lepszą ich sytuację na rynku pracy. Wskaźniki zatrudnienia w ciągu tych dziesięciu lat wzrosły prawie we wszystkich krajach, osiągając $65 \%$, o 2,5 punktów procentowych niższe w stosunku do autochtonów. W Niemczech wskaźnik zatrudnienia wynoszący 57\% w 2000 roku wzrósł do 54\% w 2010 roku, a w Wielkiej Brytanii odpowiednio z 62\% do $66 \%$. Szczególnie znaczący postęp dotyczył kobiet imigrantek, jednak rozpiętość w stosunku do kobiet autochtonek w wielu krajach jest znaczna, zwłaszcza w Holandii i Szwecji. Wskaźniki zatrudnienia zmniejszyły się tylko w krajach silnie dotkniętych kryzysem: z 70\% do 67\% w Stanach Zjednoczonych, z $62 \%$ do $57 \%$ w Hiszpanii ${ }^{1}$.

Polska wprawdzie nie jest jeszcze postrzegana jako uprzywilejowane terytorium imigracji docelowej, niemniej z każdym rokiem przybywają do naszego kraju coraz to nowe grupy imigrantów, których dzieci podejmują naukę zarówno w szkołach publicznych, jak i prywatnych.

Edukacja ma do odegrania kluczową rolę nie tylko w zapewnieniu dzieciom ze środowisk migracyjnych możliwości, dzięki którym mogłyby w pełni wykorzystać swój potencjał, ale i w tworzeniu społeczeństwa sprawiedliwego, sprzyjającego integracji i szanującego różnorodność. Jednak wiele takich dzieci nadal osiąga gorsze wyniki w nauce, a problemy związane $\mathrm{z}$ dyskryminacją rasową i etniczną oraz z wykluczeniem społecznym występują nie tylko w Europie. Obecność dużej liczby dzieci imigrantów w wielu państwach stanowi zatem wyzwanie - a zarazem cenną szansę - dla ich systemów edukacyjnych.

Polskie badania i diagnozy szkolnej praktyki wskazują na potrzebę doskonalenia kompetencji personelu pedagogicznego niezbędnych do kształtowania prawidłowych relacji z uczniami wywodzącymi się z odmiennych

1 Trouver ses marques: les indicateurs de OCDE sur l'intégration des immigrés 2012. Paris 2012, OCDE. 
kulturowo kręgów i grup etnicznych. Opublikowany przez Centrum Stosunków Międzynarodowych raport Integracja a Polityka Edukacyjna wskazuje m.in. najistotniejsze problemy i wyzwania związane z edukacją dzieci imigrantów stojące przed polskim systemem edukacji: brak systematycznego monitorowania dzieci w wieku szkolnym, łącznie z dziećmi uchodźców, uniemożliwiający rzeczywistą kontrolę wykonywania obowiązku szkolnego; brak odpowiednio wykwalifikowanej kadry nauczycielskiej, niski poziom zainteresowania pedagogów szkolnych grupą dzieci-imigrantów, a także brak wsparcia, w tym również finansowego; często postawy nauczycieli wobec dzieci-imigrantów opierają się na intencji zintegrowania ich z polskimi rówieśnikami, poprzez narzucanie im polskich wzorców dotyczących zainteresowań literackich, upodobań kulturalnych, czy nawet utożsamianie się z polskim dziedzictwem narodowym; niewystarczające zaangażowanie i współpraca władz lokalnych, dyrekcji szkół oraz pracowników socjalnych w efektywnej integracji dzieci cudzoziemskich ${ }^{2}$.

Pomocne może się okazać w tym względzie poznawanie teoretycznego dorobku i praktycznych doświadczeń krajów zarówno rodzimych, jak i zagranicznych.

Generalnie uczeń imigrant jest narażony w mniejszym lub większym stopniu na stres kulturowy, będący reakcją na zmianę otoczenia społecznego i funkcjonowania psychicznego w obcym kulturowo środowisku. Stres ten związany jest ze zjawiskiem akulturacji jednostki, procesem adaptacji psychologicznej, behawioralnej i społeczno-kulturowej na skutek kontaktu z kulturą lub kulturami innymi niż kultura pierwotnej socjalizacji. Przezwyciężanie stresu, zwłaszcza długotrwałego, odbywa się najkorzystniej w przypadku obrania przez imigranta strategii integracji (w przeciwieństwie do zamknięcia się w swojej tożsamości lub asymilacji), tj. dążenia do zachowania własnej kultury i tożsamości kulturowej pochodzenia oraz gotowości do nawiązywania kontaktu i czerpania z kultury kraju przyjmującego ${ }^{3}$. Konsekwencją jest wówczas nabywanie tożsamości dwukulturowej - wytworzenia się nowej, wewnętrznie zintegrowanej tożsamości, innej od tożsamości narodowej czy etnicznej. W kontekście refleksji na temat tożsamości i aspiracji młodzieży

2 D. Szelewa: Integracja a Polityka Edukacyjna. Raporty i analizy. Seria „Integracja”. Warszawa 2010, Centrum Stosunków Międzynarodowych, s. 33 i n. http://csm. org.pl (12.01.2013).

3 J. W. Berry, J. S. Phinney, D. L. Sam, P. Vedder: Immigrant youth: acculturation, identity and adaptation. „Applied Psychology” 2006, 55 (3), s. 303-332. 
imigranckiej z widocznych mniejszości C. Suárez-Orozco i M. Suárez-Oroz$\mathrm{Co}^{4}$ dochodzą do podobnego wniosku i wyrażają pogląd, że młodzi ludzie, którzy rozwijają „dwukulturowe kompetencje”, są najlepiej przygotowani do wykorzystania swoich możliwości, ponieważ mają silne poczucie własnej tożsamości etnicznej, lecz również rozwijają „hybrydową tożsamość i kulturową formację”, przekształcając „starą” kulturę etniczną i „nową” większościową w sposób twórczy. Z kolei Perron ${ }^{5}$ argumentuje, że uczniowie imigranci im mocniej utożsamiają się z kulturą własnej grupy, tym częściej przejawiają otwartość wobec innych grup kulturowych i jest prawdopodobne, że będą dążyć do zdobycia wykształcenia uniwersyteckiego.

Imigranci są narażeni również na inne czynniki stresogenne: poszukiwanie mieszkania i nowej pracy, poznawanie regulacji prawnych, zapoznawanie się z odmiennym systemem edukacji dla swoich dzieci.

Stopień powodzenia adaptacji imigrantów w znacznej mierze zależy również od kraju przyjmującego, jego strategii wobec imigrantów i ich kultury oraz otwartości na różnorodność kulturową, zmianę w obrębie własnej kultury. Strategie kraju przyjmującego mogą być różne: multikulturalizm, dekulturacja, melting pot (teoria tygla), segregacja. Istotne znaczenie ma również polityka migracyjna państwa (Kanada, USA, Australia versus Unia Europejska). Rada Europy, UNESCO, Unia Europejska za najkorzystniejszy model relacji zarówno dla imigrantów, jak i dla społeczeństwa kraju przyjmującego uznają integrację opartą na zasadach demokracji i praw człowieka. Integracja jest procesem dynamicznym i wielowymiarowym dokonującym się we wzajemnie od siebie zależnych wymiarach: ekonomicznym, społecznym, kulturowym, tożsamościowym, prawno-instytucjonalnym. Tak pojęta integracja pozwala zapobiec lub ograniczyć społeczną marginalizację imigrantów oraz budować spójność społeczną i postęp ekonomiczny. Jednak inkluzja polityczna, ekonomiczna i społeczna imigrantów jest procesem trudnym, zakłada dwustronność relacji między imigrantami a społeczeństwem przyjmującym, nawet w krajach tzw. starej imigracji pozostaje wciąż wyzwaniem dla kolejnych rządów.

Szereg badań interesujących się różnicami między grupami imigranckimi i społecznościami autochtonicznymi dowodzi, że dzieci imigrantów w krajach zachod-

4 C. Suárez-Orozco, M. Suárez-Orozco: Children of immigrants. Cambridge 2001, Harvard University Press, s. 118.

5 J. Perron: Ethnicity and educational aspirations of high school students. W: B. Galaway, J. Hudson (eds.): Youth in transition: perspectives on research and policy. Toronto 1997, Thompson, s. 127-134. 
nich osiągają względnie lepsze wyniki szkolne aniżeli populacja autochtonów badanych pod kątem klasy społecznej i kapitału ludzkiego. Modele teoretyczne, które traktują przede wszystkim pozycje społeczne jako źródło tych zróżnicowań, nie przynoszą wyczerpującej odpowiedzi i nie mają pełnej mocy eksplikatywnej. Poszukując czynników innych niż tradycyjne normy socjometryczne, które mogłyby wyjaśnić te zróżnicowane wyniki szkolne, badacze dochodzili do różnych wniosków. W tym nurcie badań pojawiły się wielorakie interpretacje. C. Suárez-Orozco i M. Suárez-Orozco ${ }^{6}$ sugerują, że rodzice imigranci, doznawszy rozczarowania na skutek dewaluacji w kraju osiedlenia ich dotychczasowego prestiżu, pragną narzucić swoim dzieciom wysokie aspiracje edukacyjne. James ${ }^{7}$ dowodzi, że rodzice „czarnej” młodzieży wpajają jej niejako przekonanie, że ludzie są nagradzani dzięki ciężkiej pracy i osobistemu wysiłkowi.

Do podobnych wniosków dochodzi, na podstawie badań etnograficznych życia młodzieży ze środowisk zmarginalizowanych w USA, MacLeod ${ }^{8}$, który przeciwstawia akceptacji przez grupę czarnej młodzieży dyskursu równości szans, zanegowanie, odrzucenie tej ideologii przez białą młodzież o podobnym statusie. Ten optymizm czarnej młodzieży przypisuje jej odczuciu, że uczestniczą w „zbiorowej trajektorii w górę” (a collectiv upward trajectory). Sądzi, że można więc przypuszczać, że wysokie aspiracje młodzieży imigranckiej odzwierciedlają zaakceptowanie przez jej rodziców zdyskontowanej wartości kredencjałów na rynku pracy i przeświadczenie o tym, że warunkiem sukcesu ich dzieci jest wzmożony wysiłek. Niektórzy badacze ${ }^{9}$ sądzą, że sieci społeczne społeczności imigranckich mogą również odgrywać pewną rolę $\mathrm{w}$ kształtowaniu aspiracji, wzmacniając rodzicielskie wysiłki w przekazywaniu wartości, norm i oczekiwań wobec młodzieży.

Dla ukazania trudności, z jakimi stykają się imigranci w kraju przyjmującym, realizując swój projekt migracyjny, oraz tych czynników, które spra-

6 C. Suárez-Orozco, M. Suárez-Orozco: Children of immigrants. cyt. wyd., s. 105.

7 C. James: Getting there and staying there: black's employment experience. W: P. Anisef, P. Axelrod (eds.): Transitions: schooling and employment in Canada. Toronto 1993, Thompson, s. 3-20.

8 J. MacLeod: Ain't no makin'it: Leveled aspirations in a low-income neighbourhood. Boulder 1987, Westview.

9 M. Boyd: Ethnicity and immigrant offspring. W: M. Kalbach, W. Kalbach (eds.): Perspectives of ethnicity in Canada. Toronto 2000, Harcourt, s. 139; J. Li: Parental expectations of Chinese immigrantes: A folk theory about children's school achievement. „Ras, Ethnicity and Education” 2004, 7 (2), s. 171-190. 
wiają, że dzieci imigrantów (ze środowisk defaworyzowanych), napotykając przeszkody w przebiegu kariery szkolnej, potrafią je przezwyciężać oraz odnosić sukcesy edukacyjne, może okazać się pomocna koncepcja resilience oraz kapitału społecznego.

Przez długi czas w psychiatrii, podobnie jak w psychologii klinicznej i dyscyplinach pokrewnych, koncentrowano się na czynnikach zachowań ryzykownych i dopiero w latach 70. ubiegłego wieku zaczęto zwracać uwagę na czynniki i mechanizmy, które chronią dzieci i młodzież mimo doświadczania przez nich przeciwności losu ${ }^{10}$. W rezultacie ukształtował się nurt badań nad zjawiskiem resilience, na skrzyżowaniu kilku dyscyplin, m.in. psychologii rozwojowej, psychopatologii, nauk społecznych i medycyny. Przedmiotem badań stały się procesy pozytywnej adaptacji dzieci narażonych na czynniki ryzyka i niesprzyjające warunki życia. Koncepcja resilience zrodziła się z obserwacji dzieci i młodzieży wzrastających w niekorzystnych warunkach życiowych (rodzinach dysfunkcyjnych, niebezpiecznych dzielnicach). Podjęta została refleksja nad mechanizmami podatności i odporności na ryzyko w okresie dzieciństwa, adolescencji i wczesnej dorosłości, nad znaczeniem poszczególnych czynników w różnych okresach rozwojowych, procesami, jakie leżą u podłoża działania tych czynników oraz wzajemnymi interakcjami czynników ryzyka i czynników chroniących. Wiedza o czynnikach chroniących znalazła aplikacje praktyczne, albowiem jest wykorzystywana w działaniach i programach mających na celu wzmacnianie umiejętności życiowych uczniów, umiejętności wychowawczych rodziców i nauczycieli, w rozwijaniu kontaktów z rodzicami oraz z innymi znaczącymi osobami; jest też wykorzystywana w działaniach na rzecz bezpieczeństwa i przyjaznego środowiska szkolnego lub miejsca zamieszkania.

Zasadniczym przedmiotem badań nad resilience $\mathrm{w}$ dziedzinie edukacji są warunki nauki w szkole, w klasie, relacje w grupie rówieśniczej, kontekst rodzinny i wspólnotowy, tj. ogół sytuacji występujących w szkole, rodzinie i środowisku, które chronią dzieci przed niepowodzeniami szkolnymi. Należy podkreślić, że resilience jest zjawiskiem złożonym, generowanym wieloma czynnikami chroniącymi, które wzajemnie się uzupełniają.

Wyniki wielu badań międzynarodowych ilościowych i jakościowych nad rozwojem dzieci i młodzieży w różnych niesprzyjających warunkach wska-

10 J. Mazur et al.: Czynniki chroniące młodzież 15-letnia przed podejmowaniem zachowań ryzykownych. Raport z badań HBSC 2008. Warszawa 2008, Instytut Matki i Dziecka, Zakład Ochrony i Promocji Zdrowia Dzieci i Młodzieży. 
zują, że znaczące czynniki i procesy chroniące obejmują trzy obszary: różnice indywidualne, relacje i związki z bliskimi ludźmi oraz zasoby środowiska lokalnego. Jako kategorie czynników chroniących w pozytywnej adaptacji dzieci/młodzieży w sytuacjach zwiększonego ryzyka są wymieniane:

- w obszarze pierwszym: procesy poznawcze, temperament, mechanizmy samokontroli, umiejętności społeczne, pozytywny obraz siebie, procesy motywacyjne;

- w obszarze drugim: relacje rodzice-dziecko, konstruktywni rówieśnicy, nieformalni dorośli mentorzy;

- w obszarze trzecim: dobra szkoła, zaangażowanie w konstruktywną działalność, przyjazne i bezpieczne sąsiedztwo.

Badania edukacyjne posługujące się pojęciem resilience korzystają również z pojęcia kapitału społecznego, który kładzie nacisk na znaczenie relacji społecznych. Pojęcie kapitału społecznego pozwala wyeksponować relacje korzystne („dobry” kapitał społeczny) dla rozwoju kapitału ludzkiego, pojęcie zaś resilience umożliwia ujmowanie tych relacji jako czynników chroniących uczniów w sytuacjach niesprzyjających i trudnych. Podczas gdy kapitał społeczny może obejmować wszystkie faktory (pozytywne i negatywne) związane z relacjami i interakcjami, pojęcie resilience otwiera pole analizy specyficznej, ukazującej, w jaki sposób kapitał społeczny staje się faktorem chroniącym uczniów wystawionych na ryzyko.

Abstrahując od przeglądu definicji kapitału społecznego i zajmowania określonego stanowiska w debacie na temat jego różnych ujęć, jednych wąskich, innych szerokich, autorstwa Bourdieu, Colemana, Putmana i innych, należy odnotować, że problematyką kapitału ludzkiego interesują się nie tylko poszczególni badacze, lecz również takie instytucje międzynarodowe, jak Bank Światowy, Unia Europejska i OECD. Bank Światowy ${ }^{11}$ posługuje się następującą definicją: „Kapitał społeczny społeczeństwa obejmuje instytucje, relacje, postawy i wartości, które określają interakcje między osobami i które przyczyniają się do rozwoju ekonomicznego i społecznego. Jednak kapitał społeczny nie jest sumą instytucji, które tworzą fundament społeczeństwa, ponieważ jest spoiwem, które je łączy między sobą. Jego częścią są wspólne wartości i reguły zachowania społecznego, które przejawiają się w relacjach osobowych, zaufanie oraz wspólna percepcja odpowiedzialności

11 Le capital social comme instrument de politique public. Conference internationale du 23 au 25 novembre 2001, Montréal (Québec) Canada. Rapport de synthèse, s. 16. 
obywatelskiej - elementy, które w równej mierze nie pozwalają zredukować społeczeństwa do prostego zbioru osób" [tłum. W.R.].

W sposób bardziej zwięzły OECD, w raporcie pt. O dobrobycie narodów: rola kapitału ludzkiego i społecznego, stwierdza, że „kapitał społeczny obejmuje sieci, normy, wartości oraz wzajemne zrozumienie, które ułatwiają współpracę w ramach grup lub między grupami. Należy odróżniać od niego porozumienia polityczne, instytucjonalne i prawne bardziej formalne, które odgrywają pomocniczą rolę w tym procesie"12 [tłum. W. R.].

Koncepcja resilience i kapitału społecznego znajduje między innymi zastosowanie w wyjaśnianiu procesów pozytywnej adaptacji szkolnej i społecznej specyficznej kategorii uczniów, a mianowicie wywodzących się z rodzin imigranckich. Takie podejście znaleźć można u szwajcarskich badaczek Bader i Fibbi ${ }^{13}$. Do najważniejszych czynników warunkujących przebieg kariery szkolnej ucznia imigranta zaliczają kontekst migracyjny, środowisko społeczne, szkołę, kapitał społeczny oraz zasoby psychospołeczne. Traktują je jako edukacyjne imputs (sytuację wejściową), uzyskanie zaś świadectwa/dyplomu jako edukacyjny outcome (sytuację wyjściową) bezpośredni efekt kombinacji tych czynników zewnętrznych. Nie koncentrują uwagi na specyficznych zdolnościach jednostki, jej osobowości, lecz przede wszystkim na czynnikach strukturalnych, relacyjnych i kontekstowych, które determinują i wyznaczają obszar możliwości tych dzieci.

Zdaniem wyżej wymienionych autorek, trzy czynniki determinują kontekst imigracyjny: motyw imigracji, stosunek państwa przyjmującego oraz projekt imigracyjny. Czynnikami sprzyjającymi procesowi migracji są tzw. push factors, czyli okoliczności wypychające. Motywy migracyjne mogą być różne: niestabilne stosunki polityczne, społeczne, ekonomiczne, edukacyjne, rozwój transportu, przedsiębiorstw międzynarodowych, brak spójnej polityki migracyjnej między państwami czy też posiadanie rodziny lub znajomych w kraju docelowym, jak również pull factors (tzw. czynniki przyciągające), które występują w państwie przyjmującym i do których zaliczana jest przede wszystkim możliwość podjęcia pracy, legalnej lub nielegalnej ${ }^{14}$.

12 Du bien-être des nations: le role du capital humain et social. Paris 2001, OCDE.

13 D. Bader, R. Fibbi: Les enfants de migrants: un veritable potenciel. Neuchâtel 2012, Forum Suisse pour l'Étude des Migrations et de la Population. www.migrationpopulation.ch (12.01.2013).

14 E. Marek: Migracje zagraniczne i uchodźstwo we wspótczesnym świecie. „Polityka Społeczna" 1995, 3 (1). 
W zależności od motywów, imigracje mają charakter czasowy lub definitywny, indywidualny lub rodzinny. Te wszystkie formy migracji w różny sposób wyznaczają warunki pobytu i integracji imigranta w społeczeństwie przyjmującym. Na przykład nagły wyjazd związany z działaniami wojennymi, klęskami żywiołowymi, prześladowaniami na tle narodowościowym czy etnicznym, pobyt w ośrodkach dla uchodźców, różne przeszkody administracyjne są okolicznością utrudniającą adaptację do nowych warunków, zwłaszcza dla dzieci narażonych na tak traumatyczne przeżycia. Natomiast zaplanowana migracja i dysponowanie przez migranta odpowiednim zasobem środków (psychologicznych, intelektualnych, finansowych) ułatwia integrację społeczną dziecka. Kapitał społeczny imigranta i jego poszczególne komponenty stanowią istotny determinant procesu adaptacji w kraju przyjmującym. Dla imigrantów z pobudek ekonomicznych istotne znaczenie ma pomyślna koniunktura gospodarcza w kraju docelowym. Rekrutując się najczęściej ze środowisk o niskim statusie społeczno-zawodowym, gdy ich sytuacja materialna nie ulega poprawie, kojarzą zazwyczaj swoje niepowodzenia z brakiem odpowiedniego wykształcenia. Dlatego też rodzice migranci zachęcają swe dzieci do nauki: ich kształcenie w kraju przyjmującym jest postrzegane nie tylko jako warunek awansu społecznego i ekonomicznego, lecz również staje się wtórnym uzasadnienie projektu migracyjnego i pobytu za granicą. Mimo niekorzystnej sytuacji ekonomicznej rodziców, ich postawa staje się jednym z czynników chroniących ucznia przed niepowodzeniami szkolnymi.

Pozycja prawna i związane z nią prawa i obowiązki mają zasadnicze konsekwencje dla funkcjonowania migrantów w kraju pobytu, albowiem stan prawny warunkuje modele integracji w pozostałych wymiarach życia. Stosunek państwa przyjmującego do migrantów może być pozytywny, negatywny bądź neutralny, w zależności o statusu prawnego migranta, jaki mu przysługuje w danym kraju. Stosunek ten różnicuje szanse edukacyjne dzieci migrantów. Dzieci rodziców o nieuregulowanym statusie prawnym mają mniejsze szanse na pomyślny przebieg kariery szkolnej. Zatem skolaryzacja dzieci imigrantów, przebywających w danym kraju będzie zależała między innymi od prawno-instytucjonalnej integracji ich rodziców.

Projekty migracyjne mogą ewoluować w trakcie ich realizacji. Plany pozostania na stałe w kraju przyjmującym lub powrotu po pewnym czasie do kraju pochodzenia w różny sposób oddziałują na naukę szkolną dzieci. Migranci, którzy łączą przyszłość swoich dzieci z krajem przyjmującym, przywiązują większą wagę do wyników szkolnych, zachęcają do dalszej nauki, uczenia 
się języka obcego. Decyzja pozostania na stałe wpływa na przyszłość dzieci, ponieważ awans społeczny jawi się im w nowym wymiarze: ułożenia życia w kraju pobytu. Ich determinacja w realizacji planów życiowych umożliwia przezwyciężanie barier lingwistycznych i ewentualnych przejawów dyskryminacji.

Tak więc trzy czynniki tworzą sprzyjający początkowy kontekst migracyjny: przybycie do kraju przyjmującego z przyczyn ekonomicznych (motyw migracji), uzyskanie prawa pobytu (neutralny stosunek państwa) oraz plany pozostania w kraju przyjmującym w dłuższej perspektywie czasowej.

Postmigracyjny status społeczno-ekonomiczny, struktura rodziny oraz rodzaj socjalizacji lingwistycznej, podobnie jak projekt migracyjny, stanowią początkowe determinanty kariery szkolnej ucznia imigranta, podstawę jego przyszłej mobilności społecznej. Najbardziej sprzyjającą tej mobilności konfiguracją środowiska rodzinnego jest rodzina nuklearna, w której oboje rodziców pracuje, posiadanie starszego rodzeństwa, które uczęszczało do szkoły w kraju przyjmującym oraz dwujęzyczna socjalizacja poza instytucją szkolną. System szkolny odgrywa zasadniczą rolę w przebiegu nauki i determinuje przyszły status społeczny i zawodowy dzieci imigrantów. OECD wskazuje, że im wcześniej dziecko włączane jest do systemu edukacyjnego kraju przyjmującego, tym mniej znaczące są różnice w jego osiągnięciach szkolnych w stosunku do dzieci autochtonów. W badaniach PISA (testach czytania ze zrozumieniem) stwierdzono znaczące różnice zarówno między krajami, jak i w poszczególnych krajach w osiągnięciach szkolnych dzieci imigrantów: uczniowie, którzy przybyli do kraju przyjmującego w wieku 11-16 lat, mają gorsze wyniki niż uczniowie, którzy zamieszkali w nim przed 6. rokiem życia. W Niemczech, Belgii, Islandii, Izraelu, Republice Czeskiej i Szwecji ta rozpiętość jest szczególnie duża, albowiem odpowiada mniej więcej półtorarocznej skolaryzacji. Natomiast różnica jest nieznaczna w Austrii, Luksemburgu, Wielkiej Brytanii i Szwajcarii. Ponieważ wczesna skolaryzacja w kraju pobytu ma tak istotne znaczenie, OECD sugeruje, aby kraje członkowskie zachęcały legalnych imigrantów do możliwie szybkiego sprowadzania rodzin ${ }^{15}$.

Przede wszystkim kształcenie przedszkolne i szkoła obowiązkowa stanowią zasadniczy etap w opanowywaniu języka skolaryzacji, a tym samym okres krytyczny w karierze szkolnej. Zapoznawanie się od wczesnego dzieciństwa z normami i zwyczajami społeczeństwa przyjmującego oswaja dziecko z ze-

15 OECD: Where immigrant students succeed - A comparative review of performance and engagement in PISA 2003. Paris 2006, OECD. 
wnętrznym środowiskiem społeczno-kulturowym. Jednak nie wszystkie dzieci imigrantów urodziły się w kraju przyjmującym i nie wszystkie miały możliwość uczęszczania do przedszkoli.

Poza tym systemy szkolne nie są jednolite we wszystkich krajach: występują różnice w orientacji szkolnej, kryteriach kierowania dzieci imigrantów do klas przygotowawczych lub specjalnych, dostępności kształcenia przedszkolnego, istnieniu mniej lub bardziej prestiżowych sekcji i profili kształcenia itp. Na przykład szanse kontynuowania nauki ponadobowiązkowej dającej dostęp do kształcenia uniwersyteckiego są dwukrotnie większe, jeśli porówna się sytuację dzieci imigrantów tureckich w Niemczech (późna skolaryzacja i wczesna selekcja) z sytuacją dzieci pochodzenia tureckiego w systemie szkolnym, w którym wczesna skolaryzacja idzie w parze z późną selekcją, jak to ma miejsce we Francji, Szwecji i Belgii. W niektórych krajach występuje tendencja do nieuzasadnionego kierowania dzieci imigrantów do klas lub placówek specjalnych (w niektórych kantonach w Szwajcarii i Belgii Flandrii). Różne są też rozwiązania w zakresie środków czy mechanizmów pedagogicznych podejmowanych z myślą o dzieciach imigrantów w wieku szkolnym: tworzenie klas przygotowawczych, zwłaszcza dla dzieci świeżo przybyłych imigrantów, bądź integrowanie tych dzieci w klasach zwykłych (model separacyjny lub model integracyjny) ${ }^{16}$.

Pomimo trudności systemowych, uczniowie pochodzenia imigranckiego potrafią nie poddawać się stresowi akulturacji oraz stresowi szkolnemu i konsekwentnie realizują swoje plany edukacyjne. Bader i Fibbi, wskazując na czynniki przyczyniające się do tego sukcesu, nawiązują do teorii kapitału społecznego i teorii resilience. Zgodnie z dyrektywą badań nad resilience, autorki wskazują na chroniące znaczenie konstruktywnych relacji i związków z osobami z najbliższego otoczenia: rodzicami, starszym rodzeństwem, rówieśnikami.

16 W. Rabczuk: Integracja imigrantów przez edukację. W: T. Lewowicki, A. Szczurek-Boruta, B. Grabowska (red.): Spoteczne uwarunkowania edukacji międzykulturowej. T. 2. Problemy praktyki oświatowej. Cieszyn - Warszawa - Toruń 2009, Wydział Etnologii i Nauk o Edukacji Uniwersytetu Śląskiego, Wyższa Szkoła Pedagogiczna ZNP w Warszawie, Wydawnictwo Adam Marszałek, s. 24; tenże: Zwalczanie nierówności oraz wykluczenia edukacyjnego. W: T. Lewowicki, A. Szczurek Boruta, J. Suchodolska (red.): Pedagogika międzykulturowa wobec wykluczenia społecznego. Cieszyn Warszawa - Toruń 2011, Wydział Etnologii i Nauk o Edukacji Uniwersytetu Śląskiego, Wyższa Szkoła Pedagogiczna ZNP w Warszawie, Stowarzyszenie Wspierania Edukacji Międzykulturowej, Wydawnictwo Adam Marszałek, s. 35 i n. 
Wsparcie najbliższego i dalszego otoczenia oddziałuje w istotny sposób na przebieg kariery szkolnej ucznia zarówno pochodzenia imigranckiego, jak i autochtonicznego. Jednak w odniesieniu do uczniów imigrantów ta prawidłowość ma swoją specyfikę. Ponieważ ich status imigranta implikuje szereg trudności, dlatego kapitał społeczny jest im szczególnie potrzebny. Wysokie rodzicielskie aspiracje edukacyjne korzystnie oddziałują na osiągnięcia szkolne dzieci i przeciwnie - niskie aspiracje są predykatorem gorszych osiągnięć. Aspiracje rodziców-imigrantów zależą przede wszystkim od motywów ich imigracji i planów migracyjnych, lecz również od ich statusu społeczno-ekonomicznego. Rodziny o niskim statusie postrzegają kształcenie jako drogę awansu społecznego i polepszenia warunków egzystencji, zwłaszcza gdy same w kraju imigracji podejmują pracę w najmniej rentownych i prestiżowych zawodach. W ten sposób szkoła staje się wektorem integracji w społeczeństwie przyjmującym, a kształcenie dziecka kolektywnym projektem. Wysokie aspiracje edukacyjne rodziców w odniesieniu do dzieci zmniejszają niekorzystny wpływ pochodzenia społecznego na ich rezultaty szkolne. Wsparcie rodziców, zachęta do nauki może być projekcją na dzieci ich własnych ambicji edukacyjnych, gdy sami byli pozbawieni możliwości zdobycia wykształcenia. W takich okolicznościach dzieci są świadome potencjalnych szans i wartości edukacji oraz czują się zobowiązane do odniesienia sukcesu w nauce. Wsparcie rodzicielskie staje się wówczas ważnym źródłem motywacji i samooceny. Moralne wsparcie rodziców jest całkowicie niezależne od ich kapitału ekonomicznego (zasobów materialnych) i kapitału ludzkiego (wykształcenia).

Wsparcie starszego rodzeństwa ma także istotne znaczenie: może przejawiać się w dzieleniu się swoim doświadczeniem szkolnym, w pełnieniu roli pośrednika między dorosłymi (rodzicami, nauczycielami) a młodszym rodzeństwem oraz osoby z autorytetem i opiekuna chroniącego braci i siostry przed niewłaściwym zachowaniem mogącym zniweczyć ich szanse edukacyjne.

Wspomaganie rówieśnicze może mieć charakter horyzontalny i wertykalny. Pierwsze występuje między rówieśnikami o podobnym przebiegu migracji i nauki szkolnej. Sieć przyjaciół należących do tego samego kontekstu społeczno-ekonomicznego i kulturowego, pokonujących podobne trudności na drodze do mobilności społecznej, ułatwia przezwyciężanie tych przeszkód i kompensuje brakujące zasoby dzięki silnej motywacji grupowej. Z pomocy wertykalnej, podobnie jak z pomocy okazywanej przez starsze rodzeństwo, 
korzysta młody uczeń imigrant od starszego ucznia czy studenta, pełniącego rolę repetytora lub „doradcy”.

Procesom pozytywnej adaptacji dzieci i młodzieży sprzyjają również odpowiednie zasoby środowiska, a w tym dobry klimat szkoły i wsparcie nauczycieli. Wspólnota pochodzenia (lokalna, etniczna, regionalna, narodowa) na terenie kraju przyjmującego jest cennym środowiskiem wsparcia, zwłaszcza dla nowo przybyłych migrantów. Pozytywne oddziaływanie obecności znaczącej wspólnoty etnicznej na osiągnięcia szkolne uczniów imigrantów zostały wykazane na podstawie danych PISA z 2003 roku. Wsparcie wspólnotowe uzupełnia wsparcie rodziny, zwłaszcza, gdy ma ona słaby kapitał społeczny. Wpływ szkolnego środowiska instytucjonalnego na osiągnięcia dzieci imigrantów ma nie tylko charakter strukturalny, lecz również relacyjny. Wsparcie środowiska instytucjonalnego obejmuje zindywidualizowane wsparcie uczniów przez nauczycieli oraz kontakty między rodzicami i aktorami instytucjonalnymi. Dlatego tak ważne jest wyzbycie się przez personel pedagogiczny stereotypów i uprzedzeń społecznych i etnicznych, które mogą wpływać na ocenę kompetencji uczniów imigrantów i ich przyszłych możliwości zawodowych. W niektórych kulturach Azji nauczyciel cieszy się szczególnym autorytetem i jego ocena jest często niepodważalna, może więc determinować opinię rodziców na temat zdolności ich dzieci i celowości kontynuowania przez nich nauki. Szkoła i rodzina, mimo że są odrębnymi systemami, dzięki współpracy mogą zoptymalizować swoje oddziaływanie na karierę szkolną ucznia. Zasadnicze znaczenie mają kontakty nauczycieli i doradców ds. orientacji szkolnej z rodzicami. Jednak komunikacja nieraz jest utrudniona z uwagi na nieznajomość języka kraju pobytu imigranta. Nie są to trudności nie do pokonania: możliwa jest pomoc tłumacza z danej wspólnoty, pośrednictwo dwujęzycznego ucznia lub nauczyciela uczącego języka i kultury języka pochodzenia migranta. Charakter wsparcia ma szczególnie istotny wpływ na pozytywną samoocenę oraz aspiracje edukacyjne dzieci imigrantów, na co zwracał uwagę Coleman.

Zasygnalizowane w czterech obszarach imputs edukacyjne - przebieg i projekt migracji, środowisko rodzinne, struktury kształcenia, kapitał społeczny - jak podkreślają D. Bader i R. Fibbi, mogą pozytywnie oddziaływać na osiągnięcia szkolne. Wpływ ten związany jest z rozwojem zasobów psychospołecznych, które tworzą piąty obszar. Zasoby te są pochodną motywacji i resilience.

Dzieci imigrantów, wywodzące się z rodzin niezamożnych, zawdzięczają pozytywny przebieg kariery szkolnej takim czynnikom chroniącym, umożliwiającym rozwój zdolności adaptacyjnych, jak przyjazne struktury szkolne, 
silny kapitał społeczny, wczesna samodzielność, wysokie zdolności kognitywne. Ważnym czynnikiem jest pamięć aktywna, zdolność odtworzenia i zrozumienia swojej przeszłości i przebiegu migracji na podstawie wspomnień rodzinnych (w procesie kształtowania się tożsamości) - źródło proaktywnej motywacji. Zdobywanie wykształcenia jest wówczas traktowane przez dziecko jako kontynuacja planów rodzicielskich. Ta motywacja jest wyrazem woli polepszenia warunków egzystencji oraz kompensacji wyrzeczeń rodziców, którzy nie byli w stanie urzeczywistnić swoich aspiracji. Obawa pozostania w tej samej grupie społecznej co rodzice każe dostrzegać w edukacji szansę na zmianę statusu społeczno-ekonomicznego. „Optymizm imigrancki” sprawia, że imigranci potrafią przezwyciężać trudności związane z ich statusem dzięki odporności psychicznej, której źródłem są wysokie aspiracje mobilności społecznej. Motywacja reaktywna może mieć swoje źródło w negatywnych doświadczeniach i przeżyciach związanych np. z dyskryminacją, jak również w pozytywnej samoocenie, zintegrowaniu ze środowiskiem szkolnym lub w perspektywicznych planach. Motywacja i determinacja są podstawowymi edukacyjnymi i psychologicznymi przesłankami sukcesu szkolnego i zawodowego.

Tak więc splot różnych czynników: polityka i warunki integracji w kraju przyjmującym, rodzaj socjalizacji (intraetnicznej lub interetnicznej), struktury szkolne (dostępność kształcenia przedszkolnego, selekcja szkolna) oraz kapitał społeczny (wsparcie środowiska rodzinnego i wspólnotowego, a także stosunek nauczycieli do uczniów) decydują o możliwości rozwijania u uczniów imigrantów zasobów psychospołecznych niezbędnych do przezwyciężenia przeszkód w przebiegu ich kariery szkolnej związanych z kondycją imigranta.

W tym kontekście warto zwrócić uwagę na znaczenie chroniące wymiaru normatywnego kapitału społecznego, na przykładzie grupy imigrantów pochodzenia azjatyckiego. Wymiar normatywny dotyczy wartości, norm, które charakteryzują każdą strukturę społeczną; zawiera zobowiązania, aspiracje i ideały uznawane przez członków rodziny, wspólnotę i szkoły; odnosi się do dyscypliny, aspiracji oraz oczekiwań i nagród.

Wielu autorów analizowało, w jaki sposób ten wymiar kapitału społecznego wspólnoty etnicznej może sprzyjać adaptacji szkolnej uczniów. Zhou i Bankston ${ }^{17}$, na podstawie studium przypadku dzieci wietnamskich należących do emigranckiej wspólnoty w Nowym Orleanie, zwrócili uwagę na

17 M. Zhou, C. L. Bancston: Social capital and the adaptation of the second generation: The case of Vietnamese youth in New Orleans. „International Migration Ree view" 1994, 28 (4), s. 821-845. 
różne aspekty kultury imigracyjnej pełniące funkcję kapitału społecznego, które ułatwiają adaptację dzieci imigrantów w nowym otoczeniu. Uczniowie, którzy okazują silny związek z tradycyjnymi wartościami rodzinnymi, szacunek dla etyki pracy oraz angażują się w życie wspólnoty etnicznej, wykazują wyraźną tendencję do uzyskiwania pozytywnych osiągnięć szkolnych, posiadania sprecyzowanych planów edukacyjnych oraz pomyślnego ukończenia nauki w wybranych profilach kształcenia. Postawy tych uczniów korespondują z oczekiwaniami ich wspólnoty i świadczą o niezwykle wysokim stopniu integracji oraz dowodzą, że silne więzi kulturowe u imigrantów mogą stanowić formę kapitału społecznego, który sprzyja respektowaniu wartości i konstruktywnym zachowaniom, dostarczając dzieciom ze środowisk defaworyzowanych pozytywnych faktorów chroniących i ułatwiających adaptację. Nasuwa się wniosek, że kapitał społeczny ma zasadnicze znaczenie i w pewnych warunkach odgrywa większą rolę niż tradycyjny kapitał ludzki $\mathrm{w}$ adaptacji dzieci pochodzenia imigranckiego.

W Polsce sytuację dzieci wietnamskich w szkołach badała T. Halik. Wyjaśnienia fenomenu sukcesów uczniów wietnamskich, zdaniem autorki, należy upatrywać w kulturze wietnamskiej, która wyniosła z konfucjanizmu szacunek dla ludzi dobrze wykształconych, bowiem wykształcenie było traktowane jako podstawowy środek awansu społecznego oraz podwyższenia statusu własnego rodu. Wprawdzie kultury polska i wietnamska wydają się odległe od siebie, to jednak w pewnej mierze są kompatybilne: dzięki socjalizacji pierwotnej dzieci wietnamskie spotykają się najczęściej z przychylnym stosunkiem nauczycieli, ponieważ są postrzegane jako zdyscyplinowane, pracowite, inteligentne, a ich sukces edukacyjny w szkole jest ważną wartością zarówno w kulturze wietnamskiej, jak i polskiej ${ }^{18}$.

Dyscyplina moralna, szacunek do pracy i podejmowanie wysiłku kształcenia charakteryzuje również koreańskich uczniów. Są oni silnie zmotywowani intensywną rodzicielską presją sukcesu. Takie podejście ma swoje źródło w tradycji konfucjanizmu, który eksponuje wartość edukacji i norm moralnych ${ }^{19}$. Z kolei badania $\mathrm{Yu}^{20}$ potwierdzają znaczenie czynnika kulturowego, w tym przypadku

18 T. Halik, E. Nowicka, W. Połeć: Dziecko wietnamskie w polskiej szkole. Warszawa 2006, „Prolog”, s. 180, 195-196.

19 A. Gromkowska-Melosik, T. Gmerek: Problemy nierówności społecznej w teorii i praktyce edukacyjnej. Kraków 2008, Oficyna Wydawnicza „Impuls”, s. 165; 181.

20 E. S. Yu: Chinese collective orientation and need for achievement. „International Journal of Social Psychiatry" 1980, 26 (3), s. 184-189. 
chińskiej orientacji kolektywistycznej, jako źródła generalnie silniejszej motywacji osiągnięć szkolnych u uczniów chińskich w stosunku do uczniów nieazjatyckich. Ma i Yeh ${ }^{21}$, badający chińskich uczniów szkół licealnych w Nowym Yorku, ustalili, że wysokie aspiracje edukacyjne, które cechują chińskich rodziców, korelują z aspiracjami i planami edukacyjnymi i zawodowymi ich dzieci. Podobne wnioski odnotowano w Kanadzie ${ }^{22}$ : rodzice starają się przekazać dzieciom wartości wypływające z chińskiej tradycji, stawiając sobie za cel wykształcenie dzieci oraz ich integrację w nowym środowisku społecznym.

W 2010 roku Chua, urodzona w Stanach Zjednoczonych Chinka, opublikowała książkę Battle Hymne of the Tiger Mother (Hymn bojowy matki-tygrysicy). Książka (przełożona na wiele języków, w tym język polski) wywołała szeroką dyskusję, nie tylko wśród pedagogów, na temat czynników determinujących sukces edukacyjny. Chua przeciwstawia chiński model wychowawczy permisywnej tradycji Zachodu, w której dzieci mają własną, naiwną i sentymentalną kulturę. Poza tym twierdzi, że brakuje im dyscypliny, zdolności planowania i realizowania powziętych zamiarów. Stawia prostą i prowokacyjną tezę - matki chińskie są najlepsze w świecie, ponieważ nie rozpieszczają swoich dzieci, szybko wprowadzają je do kultury dorosłych, stawiają im wysokie wymagania, są szorstkie i chłodne, ale uczą przetrwania i rywalizacji. W przeciwieństwie do typowej zachodniej matki chińska matka wychodzi z założenia, że „naukę stawiamy na pierwszym miejscu; szóstka minus to zły stopień; dziecko ma wyprzedzać resztę klasy w matematyce o dwa lata; nie należy chwalić dzieci publicznie; jeśli dziecko kiedykolwiek poróżni się z nauczycielem lub instruktorem, zawsze stoimy po stronie nauczyciela lub instruktora; dzieci mogą uczestniczyć jedynie w zajęciach, w których jest szansa na zdobycie medalu, złotego oczywiście"23.

Ten model wychowania, przekonuje Chua, jest między innymi źródłem azjatyckiej dominacji w wiodących szkołach muzycznych w Stanach Zjednoczonych, w których Azjaci i Azjoamerykanie stanowią od trzydziestu do pięćdziesięciu procent wszystkich studentów, na cenionych zaś kierunkach

21 P. W. Ma, Ch. J. Yeh: Individual and familial factors influencing the educational and career plans of Chinese immigrant youths. "Career Development Quarterly” 2010, 58 (3), s. 230-245.

22 J. Li: Parental expectations of Chinese immigrantes: A folk theory about children's school achievement. cyt. wyd.

23 A. Chua: Bojowa pieśń tygrysicy. Dlaczego chińskie matki sa lepsze? Tłum. M. Moltzan-Małkowska. Warszawa 2011, Prószyński i S-ka. 
połowę studentów, a dwie najliczniejsze grupy to uczniowie chińskiego i koreańskiego pochodzenia ${ }^{24}$.

Podobnej socjalizacji, jak Wietnamczycy, Koreańczycy i Chińczycy poddawane są dzieci i młodzież w Japonii, której zasadniczym celem jest, jak pisze Cylkowska-Nowak ${ }^{25}$, „podgrzewanie” ambicji edukacyjnych oraz wyposażenie w cechy psychiczne, które umożliwią osiągnięcie sukcesu wbrew wszelkim przeciwnościom.

Z przedstawionych powyżej refleksji wynika, że możliwe jest zwiększenie szans edukacyjnych dzieci imigrantów wywodzących się ze środowisk o niskim statusie społeczno-ekonomicznym, jeśli będzie się uwzględniać wielorakie uwarunkowania ich kondycji migranta w kraju przyjmującym. Zwrócenie uwagi na kontekstualny charakter czynników chroniących pozwala dostrzec istotne aspekty trajektorii szkolnej dzieci imigrantów.

\section{Bibliografia}

Bader D., Fibbi R.: Les enfants de migrants: un veritable potenciel. Neuchâtel 2012, Forum Suisse pour l'Étude des Migrations et de la Population. www. migration-population.ch (12.01.2013).

Berry J. W., Phinney J. S., Sam D. L., Vedder P.: Immigrant youth: acculturation, identity and adaptation. „Applied Psychology” 2006, 55 (3).

Boyd M.: Ethnicity and immigrant offspring. W: M. Kalbach, W. Kalbach (eds.): Perspectives of ethnicity in Canada. Toronto 2000, Harcourt.

Chua M.: Bojowa pieśń tygrysicy. Dlaczego chińskie matki sq lepsze? Tłum. M. Moltzan-Małkowska. Warszawa 2011, Prószyński i S-ka.

Cylkowska-Nowak M.: Społeczne funkcje szkolnictwa w Japonii i Stanach Zjednoczonych (studium z pedagogiki porównawczej). Poznań - Toruń 2000, „Edytor”.

Du bien-être des nations: le role du capital humain et social. Paris 2001, OCDE. Gromkowska-Melosik A., Gmerek T.: Problemy nierówności społecznej w teorii i praktyce edukacyjnej. Kraków 2008, Oficyna Wydawnicza „Impuls”. Halik T., Nowicka E., Połeć W.: Dziecko wietnamskie w polskiej szkole. Warszawa 2006, „Prolog”.

24. Tamże, s. 14; 258.

25 M. Cylkowska-Nowak: Społeczne funkcje szkolnictwa w Japonii i Stanach Zjednoczonych (studium z pedagogiki porównawczej). Poznań - Toruń 2000, „Edytor”, s. 198. 
James C.: Getting there and staying there: black's employment experience. W: P. Anisef, P. Axelrod (eds.): Transitions: schooling and employment in Canada. Toronto 1993, Thompson.

Le capital social comme instrument de politique public. Conference international du 23 au 25 novembre 2001, Montréal (Québec) Canada. Rapport de synthèse.

Li J.: Parental expectations of Chinese immigrantes: A folk theory about children's school achievement. "Ras, Ethnicity and Education” 2004, 7 (2).

Ma P. W., Yeh Ch. J.: Individual and familial factors influencing the educational and career plans of Chinese immigrant youths. "Career Development Quarterly" 2010, 58 (3).

MacLeod J.: Ain't no makin'it: Leveled aspirations in a low-income neighbourhood. Boulder 1987, Westview.

Marek E.: Migracje zagraniczne i uchodźstwo we wspótczesnym świecie. „Polityka Społeczna" 1995, 3 (1).

Mazur J. et al.: Czynniki chroniace młodzież 15-letnia przed podejmowaniem zachowań ryzykownych. Raport z badań HBSC 2008. Warszawa 2008, Instytut Matki i Dziecka, Zakład Ochrony i Promocji Zdrowia Dzieci i Młodzieży.

Perron J.: Ethnicity and educational aspirations of high school students. W: B. Galaway and J. Hudson (eds.): Youth in transition: perspectives on research and policy. Toronto 1997, Thompson.

Rabczuk W.: Integracja imigrantów przez edukację. W: T. Lewowicki, A. Szczurek-Boruta, B. Grabowska (red.): Społeczne uwarunkowania edukacji międzykulturowej. T. 2. Problemy praktyki oświatowej. Cieszyn - Warszawa - Toruń 2009, Wydział Etnologii i Nauk o Edukacji UŚ, Wyższa Szkoła Pedagogiczna ZNP w Warszawie, Wydawnictwo Adam Marszałek.

Rabczuk W.: Zwalczanie nierówności oraz wykluczenia edukacyjnego. W: T. Lewowicki, A. Szczurek Boruta, J. Suchodolska (red.): Pedagogika międzykulturowa wobec wykluczenia spotecznego. Cieszyn - Warszawa - Toruń 2011, Wydział Etnologii i Nauk o Edukacji UŚ, Wyższa Szkoła Pedagogiczna ZNP w Warszawie, Stowarzyszenie Wspierania Edukacji Międzykulturowej, Wydawnictwo Adam Marszałek.

Suárez-Orozco C., Suárez-Orozco M.: Children of immigrants. Cambridge 2001, Harvard University Press.

Szelewa D.: Integracja a Polityka Edukacyjna. Raporty i analizy. Seria „Integracja”. Warszawa 2010, Centrum Stosunków Międzynarodowych. http:/ csm. org.pl. 
Trouver ses marques: les indicateurs de OCDE sur l'intégration des immigrés 2012. Paris 2012, OCDE.

OECD: Where immigrant students succeed - A comparative review of performance and engagement in PISA 2003. Paris 2006, OECD.

$\mathrm{Yu}$ E. S.: Chinese collective orientation and need for achievement. „International Journal of Social Psychiatry" 1980, 26 (3).

Zhou M., Bancston C. L.: Social capital and the adaptation of the second generation: The case of Vietnamese youth in New Orleans. "International Migration Review" 1994, 28 (4).

\section{Unfavourable and protective factors in school career of immigrant learners}

\section{Summary}

The article presents the range of immigration and its socio-economic significance in OECD countries as well as improvement in the quality of immigrant children's education over the last decade. Yet, education of immigrants' children still constitutes a serious challenge for school systems. These children are exposed to cultural stress, which results in hindrance in their school adaptation. Although they come from disadvantaged environments, they achieve relatively better academic results than the autochthonous population at a similar socio-economic status. What is needed to explain this phenomenon is taking into account the notion of resilience and of social capital. The notion of social capital allows for emphasizing favourable relations ('good' social capital) for the development of human capital, whereas the notion of resilience enables viewing these relations as factors protecting learners in unfavourable and difficult situations. The discussed studies of Swiss authoresses, D. Bader and R. Fibbi, are comprised in the research into the phenomenon of resilience. The article is completed with the author's reflection on the crucial role of the normative dimension of cultural capital which immigrants (of Asian origin) possess and which facilitates the processes of positive school and social adaptation of children, in this way enlarging the resources of protective factors.

Key words: learners of immigrant descent, school adaptation, social capital, protective factors 